\title{
Gamification Based On Blockchain Technology To Enhance Student Centered Learning
}

\author{
Qurotul Aini*1, Ninda Lutfiani ${ }^{2}$, Muhammad Suzaki Zahran ${ }^{3}$ \\ ${ }^{1,2}$ Program Magister Departemen Informatika, Fakultas Sains dan Teknologi, Universitas \\ Raharja \\ ${ }^{3}$ Program Studi Sistem Komputer, Fakultas Sains dan Teknologi, Universitas Raharja ${ }^{3}$ \\ Email: *11 aini@ raharja.info, ${ }^{2}$ ninda@ raharja.info, ${ }^{3}$ m.suzaki@ raharja.info
}

\begin{abstract}
Gamification, the application of mechanical game techniques in non-game contexts, has become the primary choice that underlies current education. Educational gamification can provide solutions to problems that arise due to traditional learning methods considered less under current human behavior. Blockchain has become a hot topic of discussion that is overgrowing in recent years. Blockchain comes from a world community and company that acts as infrastructure technology that develops in various fields, both industry and education. The main advantage of blockchain is that it is free from third parties so that the security, transparency, and integrity of the blockchain is quite high. At present, research on the blockchain that is implemented in the field of educational gamification is still minimal in number. Our paper will identify and discuss the main problems related to education by implementing educational gamification applied to the Blockchain system. This paper proposes an initial gamification model as a foundation for the development of future applications and research.
\end{abstract}

Keywords - Blockchain, Gamification, Motivation, Decentralized Application, Education

\section{INTRODUCTION}

The bitcoin protocol introduced by Satoshi Nakamoto ${ }^{[1],[2]}$ in 2008 marked a change in the era of a global software decentralization system. Blockchain marks a paradigm shift from centralization to decentralized computing and has been overgrowing in academia and industry [3], [4]. One of the advantages possessed by the blockchain is that it is free from third parties ${ }^{[5]}$, ${ }^{[6]}$. This advantage makes blockchain a top choice in various innovative business models and start-ups. Over the past ten years, the development of the blockchain has varied greatly to various possible industries ${ }^{[7],}{ }^{[8]}$. However, these things have not been supported by the existence of research forums on the blockchain yet. At present, research forums on the blockchain are still minimal in number, although in the academic realm, it is at least able to approach it ${ }^{[9]}$. However, the development of a blockchain is still the innovator's authority and the initial owner of the blockchain itself. Active participation and engagement from users can be a significant problem that can hamper the stability and usefulness and development of the system.

Gamification ${ }^{[10]-[12]}$ has become a popular and new trend among individuals and groups in cyberspace in recent years. The primary purpose of gamification is to increase the role, motivation, and performance of users in carrying out specific tasks by combining the game's mechanisms and elements, which results in increasingly productive tasks [13], [14], [15]. The addition of features similar to this game has been known by many parties. It has applied to several applications, including enterprise information systems ${ }^{[16]-[18]}$, mobile and web applications ${ }^{[19],[20]}$ and IoT applications ${ }^{[21]-[23]}$. The use of gamification has been widespread in various fields ${ }^{[13],[24]}$. We have unconsciously felt the implementation of this blockchain, such as in education (for example, Zenius who applies learning methods with interesting and 
conceptual motivations to keep users interested in learning), lifestyles (such as freedom to shop online with various payment methods). It makes gamification can increase the attractiveness of multiple technologies by involving users in each task they do [7], [24], [25]. Therefore, many industries have begun to adopt gamification along with the principles of game design to attract interest and reduce the decline in users [26], [27], [28]-[30]. Also, the idea underlying gamification is useful for dealing with problems involving humans in the scope of the blockchain by discussing current issues and areas that might be useful in gamification [31], [14], [29]. This study aims to discover how to modify a blockchain system that can fundamentally change the business value by making and realizing it better. This research is intended explicitly for researchers as scientific disciplines to explain future research and practice directions in the field of blockchain gamification. Besides, this paper also presents an initial forum as a first step to discuss issues that centered on humans arising from the existence of this new technology.

The other sections of this paper's composition are as follows: Part II presents works that represent gamification in software and software engineering tasks and gives the background needed by the blockchain components. Section III explains the problems related to education and the blockchain system and the outline of the proposed gamification model. Part IV negotiates aspects related to game mechanics and a list of games suggested for the blockchain system. Section V provides conclusions on the results of the analysis that have been given.

\section{LATEST RESEARCH AND BACKGROUND}

This section will discuss market products/projects that combine gamification with blockchain to create a combination of gamification (part II.B) and also the adaptation of gamification to various software engineering activities through the R\&D method (part II.A).

\subsection{Software Engineering with Gamification}

Fundamentally, software engineering is a collaborative process in a volatile environment with humans as the center. This process will later provide gamification benefits as good reciprocity in the form of increasing the role and motivation of software engineers in carrying out their duties ${ }^{[32]}$. Thus, gamification can antidote to the manifestation of problems related to software engineering that have not been actively involved. Currently, the education industry has also widely adopted for research in the field of software engineering. It intended to overcome problems that centered on humans at various levels. Therefore, the education industry is the biggest supporter of gamification technology with the intention of learning.

Based on our literature research, gamification has been applied and utilized with various objectives and applications by focusing on improving conventional techniques or processes. The reliability requirements ${ }^{[33]}$, and priority ${ }^{[34]}$, task tracking software ${ }^{[35]}$, testing software ${ }^{[36]}$, and the like are examples of the application of gamification. These works and similar studies that have studied can motivate the use of gamification systems and engineering software. These works and related studies have been proven by the software engineering community who saw an unusual increase in associating gamification with other fields.

\subsection{The Realm of Gamification as a Form of Application of the Blockchain System}

Some systems that aim to improve the blockchain to supply solutions to gamification problems are HoToKen ${ }^{[37]}$, Sandblock ${ }^{[38]}$, and POINTToken ${ }^{[39]}$. These systems run rewards and loyalty programs on the blockchain system by applying rewards and points ${ }^{[40]}$ collected in an integrated whole and distributed to users through different parties. Based on this system, blockchain promises benefits in rewards and loyalty programs such as secure records, transparency, and ease of transactions using crypto tokens. Besides, there are general criticisms that highlight centralized loyalty by assuming that gamification only made to 
maximize company profits and make it difficult for users to accept rewards and loyalty for users' hard work ${ }^{[41]}$.

Meanwhile, the blockchain system also has several weaknesses. The weakness of the Blockchain system can be divided into two, namely the lack of understanding of blockchain applications, which results in new problems in gamification that hinder the use of blockchain gamification and reward systems (the core of this paper). And then blockchain is also not the primary choice for storing frequently updated data (such as points and rewards). Most blockchain-based systems require the transfer of data from a centralized database to decentralized public ledgers that exist on the blockchain. The system resulting from this database transfer is relatively slower in terms of expenditure; it also requires a reasonably high cost. Each transaction move requires a fee for network verification.

Also, platforms that implement a blockchain system in implementing educational models similar to this game are few. For example, brainly learning sites ${ }^{[42]}$, this site adopts a social learning model ${ }^{[43]}$ developed by Albert Bandura ${ }^{[44], ~}{ }^{[45]}$ in 1925 in its learning method so that it can invite users (in this case students) to be directly involved in crowd learning. Crowd learning ${ }^{[46]}$ defined as learning by interacting with one another using the web, social abilities, and a broad range of scope so that it can focus on existing problems using iLearning ${ }^{[47]-[49]}$, as well as stimulating interactions and ideas -ide users in solving these problems. Brainly is also able to attract the interests of users/students with different levels ${ }^{[42]}$. Also, Brainly applies a reward system in the form of points as an award for users who can answer questions correctly. Users will later use these points in making the questions they need. This method will stimulate the user to collect as many points as possible to make the questions they need.

On the other hand, there are also Quipper ${ }^{[50]}$, Ruang Guru ${ }^{[51]}$, and Zenius ${ }^{[52]}$. They implement the same thing to trigger the motivation of users/students to be actively involved in the learning process. Each platform has its characteristics that distinguish how to unleash the motivation of these users. Quipper uses a point system as a reward for completing each learning video made. These accumulated points can used to change the theme and also the background on the quipper learning page. This method is felt to be very useful because it can reduce the boredom of users/students to the static environment ${ }^{[53]}$. Different from the Ruang Guru, which puts forward a leveling system that can be accessed using points obtained from the previous level. Besides, the Ruang Guru also applies the method of repetition like a game in general to trigger student curiosity in reaching a certain level. Zenius also used the concept of the game to the idea of learning videos so that it made the user/student more curious and interested in the material studied.

The conclusion of what has been discussed is that we begin this paper by conducting discussions that aim as an initial step to get into more in-depth theory and empirical research on the infrastructure of the software engineering community. Based on our literature study results, current research works are inadequate to support and investigate all aspects of the blockchain decentralization technology and gamification technology.

\subsection{Background of Blockchain Components}

Blockchain technology is an integrated technique connected with various infrastructures such as cryptography, distributed consensus algorithms, economic modeling, and peer-to-peer networks. Overall, the blockchain described as follows:

- A strategy for making irreversible ledgers, originating from and for participants on a broadcast network.

- A strategy for expressing consensus as ledger entries, such as transaction validation.

- A strategy to incentivize consensus.

In the blockchain network system, there is a particular group or exclusive among users who can verify each transaction ${ }^{[54], ~[55] ~(i n c l u d i n g ~ c l o s i n g ~ a n d ~ m a k i n g ~ c o n t a c t s ~ o r ~ c h a n g i n g ~}$ transaction statements). These special groups are called miners (in the proof-of-work 
consensus method) and minters (in the proof-of-work consensus method). The miners and minters cause the level of security on the blockchain network system is quite high because each transaction can appropriately be controlled. Also, the blockchain uses the broadcast network to ensure that all participants on the blockchain process the same transaction list for approval. Most blockchain networks use the Elliptic Curve Digital Signature Algorithm (ECDSA) ${ }^{[56]}$ to process transactions on the blockchain. However, other signature algorithms can be used, such as the Rivest-Shamir-Adleman (RSA) algorithm [57], [58], and Digital Subtraction Angiography (DSA). Each transaction that occurs will trigger a well-defined process to produce a status change in the information system represented by the blockchain.

On the blockchain, the identification system can be done directly or indirectly. Direct identification can be made in the form of proof-of-stake (PoS), while indirectly in the form of proof-of-work (PoW). In the PoW method, miners are assigned to solve advanced mathematical problems that aim to solve the ID that will be used by the next block. Miners who successfully break the ID will get a reward in the form of incentives and will be given the right to add the block and also recognize that the block is his. Mathematical troubleshooting related to this block ID requires the previous block ID. This problem causes the block id to be conserved because the block IDs are bound to one another. Changing one block ID in several blocks can change the ID in the next blocks. Whereas in the PoS method, minters will be chosen based on deterministic methods, which is a method in which minters will be chosen based on their stake. The PoS method arises due to criticism of the PoW method, which overly exploits resources and also computational energy. Therefore, validation using $\mathrm{PoS}$ is called forging or minting.

In contrast to PoS, validation by the PoW method is called mining. However, several scientific works and a group of people, many use mining as a symbol of validation with both methods. In the PoS method, minters will not be given rewards in recognition of the results of the creation of new blocks, but minters will still be paid an amount following their stake as a certification of the truth of each transaction made. Deliberate or unintended errors will affect the stake payment they will receive.

\section{EDUCATION GAMIFICATION WITH THE BLOCKCHAIN SYSTEM}

This section will identify and discuss the main problems of motivation and user curiosity in a decentralized blockchain-based system (sections III.A and III.B). The initial model we propose here is intended to facilitate the problems discussed and the risks of related problems (section III.C). This proposed model has no licensing because it is designed using a public blockchain that does not require licensing, such as access restrictions, and also intended for a decentralized system. It involves as many users as possible in the consensus process.

\subsection{Participation of Passive Users}

The block validation process is at the root of this problem, which indirectly causes problems for the system's considerable use. This problem is because the blockchain system is very dependent on active participants. Based on experience, this passive user can be a threat to the success of the owner of the blockchain system, both in the form of cryptocurrency and non-crypto currency.

Most users use technical skills that are high enough to use PoS and PoW mining methods. This thing also causes passive users who are less motivated because of the level of complexity that these users have not mastered. Because of this passive user, there is a difference in sustainability and justice in the long run. 


\subsection{Decreased Curiosity Until the Loss of User Motivation}

Related to the previous problem, the second problem that we will discuss here is the problem of decreasing user curiosity that has the potential to lose user motivation. User curiosity ${ }^{[59]}$ serves as the user's fuel (in this case, students) following the education process using gamification. Therefore, if the user's curiosity continues to increase and their educational history, this can maintain and trigger their motivation to participate in this gamification application actively. A decrease in user curiosity can be triggered by several things, some of which are boredom. Boredom ${ }^{[60],}{ }^{[61]}$ arises due to several factors, such as environmental or static environment, where the situation does not change and tends to be rigid, but also because the level of difficulty experienced by users does not increase gradually ${ }^{[62]}$. The level of difficulty that is not gradual has a great opportunity in causing boredom users to carry out the education process. This matters because if users are always faced with difficulties that are equivalent or too far or high compared to their abilities, these users tend to get bored because of the inability to translate their information to the problems they face. This boredom can reduce user curiosity to eliminate the user's motivation to become a passive user eventually. In addition to these two factors, the user's dissatisfaction with the achievement or reward obtained also can reduce the level of user curiosity in active participation. Thus, it is necessary to ensure that the user gets the satisfaction that he receives to continue to explore new things in the gamification education process.

After discussing this problem, in the next sub-section, we will discuss how these problems can be efficient by incorporating gamification into the blockchain system on relevant tasks.

\subsection{Solution: RPG Gamification}

Based on the problems described above, we suggest creating an absorbing gamification layer at the necessary level of application and an easy to understand and simple interface. This matters can increase the motivation and curiosity of users (in this case, students) to continue to participate in the application of the gamification application actively. Also, this gamification layer must, implicitly or not, provide education to the user. However, it should be remembered that the presentation of education must be delivered interestingly so that full focus is obtained from the user so that the information to be conveyed is well distributed. Delivery of this education can be implemented by adding some additional features. These additional features include learning to use flashcards, using images that can spark user interest, or using games (of course, we will not explain this further) such as puzzles, word search, and sorting. As well as feature levels, points, and rewards that can support increasing user motivation in the learning process. Giving points and rewards to users when able to complete a challenge can provide satisfaction to the user. Besides, providing a second chance to the user can also increase the user's curiosity in completing their mission. In these ways, the user/student can learn without them knowing. In other words, we can force users to learn in a fun way without making them bored or even frustrated, like learning with traditional methods [60], [63].

Related to awards, giving awards to users who have achieved extraordinary achievements in the learning process needs to be implemented in a structured and fair manner. This action because the achievement of exceptional users requires more effort and ability than the effort and ability of users in general so that the provision of appropriate awards needs to be applied. This award can be in the form of a dynamic ranking from users and bonuses that specific users can receive after reaching certain stages. 


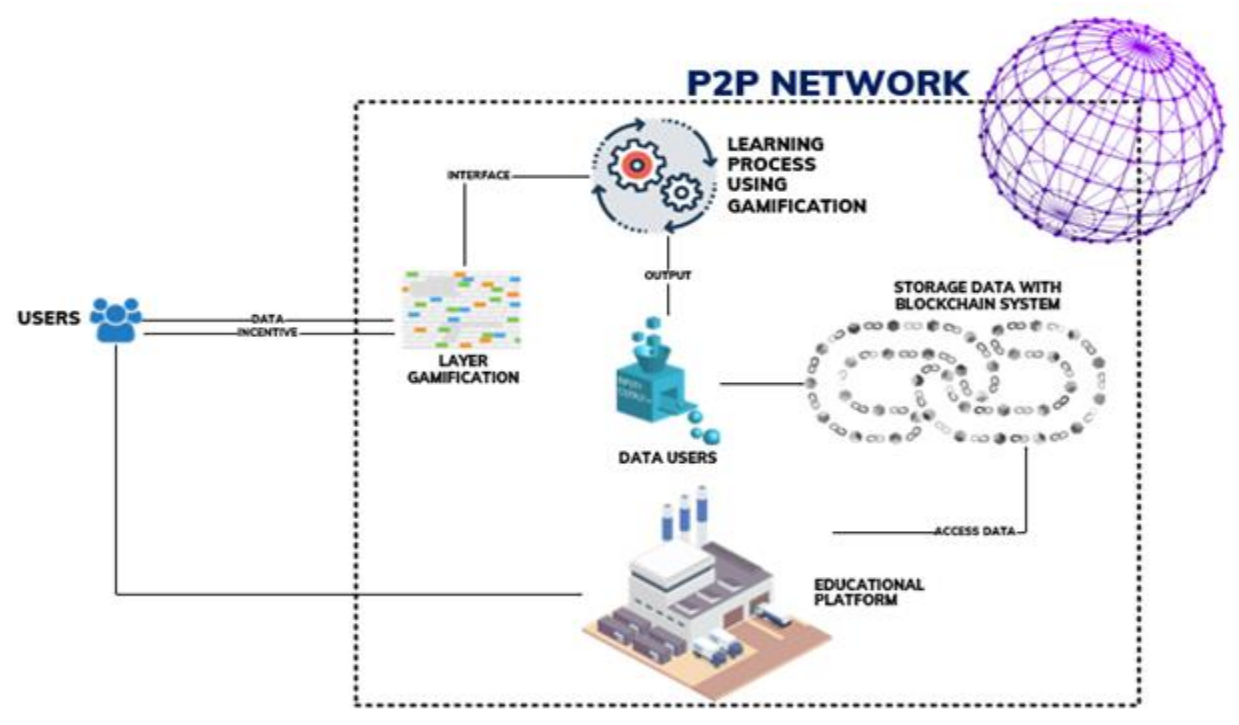

Figure 1. Conceptual View Of The Proposed Model

Figure 1 above is a model of a simple concept that we recommend. Of course, this model needs further development to apply the gamification layer used efficiently. In the above model, all transactions or activities occur in the P2P network so that users play an active role in every activity that they will carry out. The user will be faced directly with the gamification layer to carry out learning activities indirectly so that the user unconsciously undertakes a fun learning process. After the learning process is implicit, output in the form of the user's data will produce. This user data contains every user information in the form of learning outcomes, levels, incentives. After the output is generated, it will be put into storage using a blockchain system so that data security and transparency can be guaranteed well. However, this data storage can only be accessed directly by the education platform that oversees it. Therefore, users who want to access their data directly can contact the education platform. These things aim to maintain the security of user data.

Choosing the right gamification layer might be the most difficult challenge faced in educational gamification. This is because each user must have a different learning method in learning. Not to mention the support of learning material that is usually able to reduce users' motivation to learn it. Technically, the creation of gamification education similar to this game can be applied using tools that come from various platforms, such as Unity ${ }^{[64]}$, Fusion ${ }^{[65]}$, Android Studio ${ }^{[66]}$, and so on (will not be explained in detail), in order supports exciting applications. The use of these tools also requires specific programming languages, such as Java, C \#, and python, to build the gamification layer as expected.

\section{DISCUSSION}

This section will discuss points related to the proposed model and its practical implementation.

\subsection{What Games Mechanics May Be Used in the Field of Blockchain-Based Education Gamification?}

Based on the popular game with the general public in Indonesia, the possibility of the game is in the form of a role-playing game (RPG). This game involves users where users will play the characters they like (such as archers, players, fighters) and play together to complete specific missions in the predetermined storyline. This RPG game is expected to improve the user's ability to learn material that they indirectly receive so that they can learn about anything 
with ease. With this game, the application of the concept of joint learning (social learning) improves the ability to work together from users in a group or team.

Based on this case, we review the literature on game design and identify the motivational elements that are technically incorporated in gamification design in some recent studies. Regarding this, the table below shows what elements are recommended for adoption in gamification.

Table 1. Recommended Recommendations Element List

\begin{tabular}{|l|l|}
\hline Elements & Influence / Benefits \\
\hline Evecial & $\begin{array}{l}\text { Increase social activities in the gamification so that } \\
\text { users can communicate and work together with other } \\
\text { users, such as holding battles between teams at PUBG, } \\
\text { and interactions between characters at the sims. }\end{array}$ \\
\hline Token Spent & $\begin{array}{l}\text { Search for and process tokens (assets) of users and } \\
\text { record user transaction activities. }\end{array}$ \\
\hline Point & $\begin{array}{l}\text { Extrinsic rewards and improved statistics from time to } \\
\text { time }\end{array}$ \\
\hline Feedback & $\begin{array}{l}\text { Grants support and motivation to users, as well as } \\
\text { connecting users with each other. }\end{array}$ \\
\hline Consensus & $\begin{array}{l}\text { The gamification layer provides a vital incentive } \\
\text { mechanism for users to get consensus from all users } \\
\text { (one of the principles of transparent, decentralized } \\
\text { application). This type of mechanic game contains a } \\
\text { consensus state of all active users involved. }\end{array}$ \\
\hline
\end{tabular}

To encourage and support user motivation and curiosity, the five-game mechanisms may apply at various levels/levels of users that have been represented in the table above. Implementation of each model requires applying this game mechanism (as well as other additional features which will explain in the next section), which uses a kind of vector model, where each dimension of the elements corresponds to other mechanisms present in the educational gamification application.

\subsection{How to Provoke User Motivation in the Application of Educational Gamification to Prevent Decreased User Interest?}

A way that might be efficient and effective in provoking user motivation is to provide rewards/points and also points that can have an impact on user satisfaction. Besides, holding a joint race to complete a particular mission and also providing a tag (a unique sign of the user's achievement) can have a high potential in provoking user motivation. These things because humans are attracted to things that are challenging. Giving motivation and praise to users can increase the user's enthusiasm for completing the missions they are currently living. Therefore, by developing these things, it is believed that it can provoke the user's motivation so that the previously conveyed boredom can be avoided. The reduction of active users can be overcome.

\subsection{How Can Adjust the Gamification Layer With Different User Learning Methods?}

In order to adjust the gamification layer to the user's learning method, the use of menus to select the type of mission that users wish to face can help overcome this problem. With this different type of menus, users can adjust their learning method with the learning method provided in the menus. With that, users unconsciously forced to follow the learning methods available in the game. 


\section{CONCLUSION}

In recent years, gamification has become the sector that is most viewed nowadays. This is because gamification can be applied in various ways, from the industrial sector to the education sector. Gamification can attract users' interest in carrying out the available tasks. Coupled with the existence of a reward system and badges that can increase user motivation in completing tasks. Therefore, gamification has begun to be adopted by many academia in the hope that users (in this case students) can be more motivated in the lessons received. Also, the application of gamification can be combined with a blockchain system which can help develop the education system to a further level.

Another advantage of implementing gamification in the world of education using the blockchain system is that it can reduce user boredom in the existing process. This is based on the behavior of users who usually become passive when boredom arises. This passive behavior can be reduced in many ways, such as creating dynamic environments. Also, make the difficulty level according to the user's learning level because the level of difficulty can affect the enthusiasm and motivation of users in completing existing tasks. This research suggests using the RPG game model for education because it is considered the most suitable for inviting and increasing user motivation and curiosity in the available learning process.

Of course, this research is only based on existing kinds of literature and has not yet explored the user application level. It is hoped that with this research, the model can be applied to the real world and can help develop future research.

\section{REFERENCES}

[1] S. Nakamoto, "Bitcoin P2P e-cash paper," Mail Arch., p. 1, 2008, doi: 19:4:25 -0800. msg09997.

[2] F. P. Oganda, U. Rahardja, Q. Aini, M. Hardini, and A. S. Bist, "BLOCKCHAIN: VISUALIZATION OF THE BITCOIN FORMULA," PalArch's J. Archaeol. Egypt/Egyptology, vol. 17, no. 6, pp. 308-321, 2020.

[3] A. Iamnitchi et al., "Edge-centric Computing," ACM SIGCOMM Comput. Commun. Rev., vol. 45, no. 5, pp. 37-42, 2015, doi: 10.1145/2831347.2831354.

[4] B. S. Riza, "Blockchain Dalam Pendidikan: Lapisan Logis di Bawahnya," ADI Bisnis Digit. Interdisiplin J., vol. 1, no. 1, pp. 41-47, 2020.

[5] S. Kosasi, "Karakteristik Blockchain Teknologi Dalam Pengembangan Edukasi," ADI Bisnis Digit. Interdisiplin J., vol. 1, no. 1, pp. 87-94, 2020.

[6] L. Chandra, Amroni, B. Frizca, Q. Aini, and U. Rahardja, "Utilization Of Blockchain Decentralized System In Repairing Management Of Certificate Issuance System," J. Adv. Res. Dyn. Control Syst., vol. 12, no. 2, pp. 1922-1927, 2020, doi: 10.5373/JARDCS/V12I2/S20201235.

[7] N. Lutfiani, F. P. Oganda, C. Lukita, Q. Aini, and U. Rahardja, "Desain dan Metodologi Teknologi Blockchain Untuk Monitoring Manajemen Rantai Pasokan Makanan yang Terdesentralisasi," InfoTekJar J. Nas. Inform. dan Teknol. Jar., vol. 5, no. 1, pp. 18-25, 2020.

[8] N. Lutfiani, E. P. Harahap, Q. Aini, A. D. A. R. Ahmad, and U. Rahardja, "Inovasi Manajemen Proyek I-Learning Menggunakan Metode Agile Scrumban," InfoTekJar J. Nas. Inform. dan Teknol. Jar., vol. 5, no. 1, pp. 96-101, 2020.

[9] P. A. Sunarya, U. Rahardja, L. Sunarya, and M. Hardini, "The Role Of Blockchain As A Security Support For Student Profiles In Technology Education Systems," InfoTekJar J. Nas. Inform. dan Teknol. Jar., vol. 4, no. 2, pp. 13-17, 2020.

[10] I. Caponetto, J. Earp, and M. Ott, "Gamification and education: A literature review," Proc. Eur. Conf. Games-based Learn., vol. 1, no. 2009, pp. 50-57, 2014.

[11] A. G. A. Cayton-hodges et al., "Gameification in Education: A Systematic Mapping Study," vol. 18, no. 2, pp. 3-20, 2018. 
[12] U. Rahardja, Q. Aini, H. D. Ariessanti, and A. Khoirunisa, "Pengaruh Gamifikasi pada iDu (iLearning Education) dalam Meningkatkan Motivasi Belajar Mahasiswa," NJCA (Nusantara J. Comput. Its Appl., vol. 3, no. 2, pp. 120-124, Dec. 2018, doi: 10.36564/njca.v3i2.85.

[13] H. T. Sukmana, T. Hariguna, N. Lutfiani, and U. Rahardja, "Exploring the moderating effect of technology readiness of user intention in the context of mobile payment service,” Int. J. Adv. Trends Comput. Sci. Eng., vol. 8, no. 1.5 Special Issue, pp. 249257, 2019, doi: 10.30534/ijatcse/2019/4481.52019.

[14] U. Rahardja, Q. Aini, and A. Khoirunisa, "Effect of iDu (iLearning Education) on Lecturer Performance in the Lecture Process," Aptisi Trans. Manag., vol. 2, no. 2, pp. 140-148, 2018.

[15] Q. Aini, I. Dhaniarti, and A. Khoirunisa, "Effects of iLearning Media on Student Learning Motivation," Aptisi Trans. Manag., vol. 3, no. 1, pp. 1-12, 2019.

[16] J. Swacha, "Gamification in Enterprise Information Systems: What, why and how," Proc. 2016 Fed. Conf. Comput. Sci. Inf. Syst. FedCSIS 2016, vol. 8, pp. 1229-1233, 2016, doi: 10.15439/2016F460.

[17] P. Herzig, M. Ameling, and A. Schill, "A generic platform for enterprise gamification," Proc. 2012 Jt. Work. Conf. Softw. Archit. 6th Eur. Conf. Softw. Archit. WICSA/ECSA 2012, pp. 219-223, 2012, doi: 10.1109/WICSA-ECSA.212.33.

[18] P. Herzig and P. Classification, "Gamification for Enterprise Architectures US20140051506A1," vol. 1, no. 19, 2014.

[19] F. Khaddage, C. Lattemann, and R. Acosta-Díaz, "Mobile Gamification in Education Engage, Educate and Entertain via Gamified Mobile Apps," Proc. Soc. Inf. Technol. Teach. Educ. Int. Conf. 2014, no. MARCH, pp. 1654-1660, 2014, [Online]. Available: http://www.editlib.org/p/131010.

[20] B. Monterrat, E. Lavou, B. Monterrat, and E. Lavou, "Motivation for Learning: Adaptive Gamification for Web-based Learning Environments To cite this version: Motivation for Learning: Adaptive Gamification for Web-based Learning Environments," 2015.

[21] A. Alla and K. Nafil, "Gamification in IoT application: A systematic mapping study," Procedia Comput. Sci., vol. 151, pp. 455-462, 2019, doi: 10.1016/j.procs.2019.04.062.

[22] I. Lee and K. Lee, "The Internet of Things (IoT): Applications, investments, and challenges for enterprises," Bus. Horiz., vol. 58, no. 4, pp. 431-440, 2015, doi: 10.1016/j.bushor.2015.03.008.

[23] F. Paganelli, G. Mylonas, G. Cuffaro, and I. Nesi, "Experiences from using gamification and IoT-based educational tools in high schools towards energy savings," Lect. Notes Comput. Sci. (including Subser. Lect. Notes Artif. Intell. Lect. Notes Bioinformatics), vol. 11912 LNCS, no. 696029, pp. 75-91, 2019, doi: 10.1007/978-3-030-34255-5_6.

[24] Sudaryono, N. Lutfiani, Suseno, and Q. Aini, "Empirical Study of Research Performance Leading to Education 4.0 using the iLearning Method," Int. J. Adv. Trends Comput. Sci. Eng., vol. 8, no. 1.5, pp. 264-268, Nov. 2019, doi: 10.30534/ijatcse/2019/4681.52019.

[25] Q. Aini, N. Lutfiani, F. Hanafi, and U. Rahardja, "Application of Blockchain Technology for iLearning Student Assessment," IJCCS (Indonesian J. Comput. Cybern. Syst., vol. 14, no. 2, 2020, doi: 10.22146/ijccs.53109.

[26] D. Gears and K. Braun, "Gamification in Business : Designing Motivating Solutions to Problem Situations," Chi-Conference Hum. Factors Comput. Syst., p. 5, 2013, doi: 10.1145/2468356.2479662.

[27] D. L. Kappen and L. E. Nacke, "The kaleidoscope of effective gamification: Deconstructing gamification in business applications," ACM Int. Conf. Proceeding Ser., pp. 119-122, 2013, doi: 10.1145/2583008.2583029.

[28] Q. Aini, S. Riza Bob, N. P. L. Santoso, A. Faturahman, and U. Rahardja, "Digitalization of Smart Student Assessment Quality in Era 4.0," Int. J. Adv. Trends Comput. Sci. Eng., vol. 9, no. 1.2, pp. 257-265, Apr. 2020, doi: 10.30534/ijatcse/2020/3891.22020. 
[29] Q. Aini, M. Budiarto, P. O. Hadi Putra, A. Khoirunisa, N. P. L. Santoso, and U. Rahardja, "Gamified education practice: Designing with e-commerce and ilearning concept," Int. J. Psychosoc. Rehabil., vol. 24, no. 7, 2020, doi: 10.37200/IJPR/V24I7/PR270799.

[30] Henderi, Q. Aini, N. P. L. Santoso, A. Faturahman, and U. Rahardja, "A proposed gamification framework for smart attendance system using rule base," J. Adv. Res. Dyn. Control Syst., vol. 12, no. 2, pp. 1827-1838, 2020, doi: 10.5373/JARDCS/V12I2/S20201226.

[31] U. Rahardja, S. Kosasi, E. P. Harahap, and Q. Aini, "Authenticity of a diploma using the blockchain approach,” Int. J. Adv. Trends Comput. Sci. Eng., vol. 9, no. 1.2 Special Issue, pp. 250-256, 2020, doi: 10.30534/IJATCSE/2020/3791.22020.

[32] G. Barata, S. Gama, J. Jorge, and D. Goncalves, "Engaging engeneering students with gamification," 2013 5th Int. Conf. Games Virtual Worlds Serious Appl. VS-GAMES 2013, 2013, doi: 10.1109/VS-GAMES.2013.6624228.

[33] J. Fernandes, D. Duarte, C. Ribeiro, C. Farinha, J. M. Pereira, and M. M. Da Silva, "IThink: A game-based approach towards improving collaboration and participation in requirement elicitation," Procedia Comput. Sci., vol. 15, pp. 66-77, 2012, doi: 10.1016/j.procs.2012.10.059.

[34] P. Busetta, F. M. Kifetew, D. Munante, A. Perini, A. Siena, and A. Susi, "ToolSupported Collaborative Requirements Prioritisation,” Proc. - Int. Comput. Softw. Appl. Conf., vol. 1, pp. 180-189, 2017, doi: 10.1109/COMPSAC.2017.243.

[35] . M. Parizi, A. Kasem, and A. Abdullah, "Towards gamification in software traceability: Between test and code artifacts," ICSOFT-EA 2015 - 10th Int. Conf. Softw. Eng. Appl. Proceedings; Part 10th Int. Jt. Conf. Softw. Technol. ICSOFT 2015, pp. 393-400, 2015, doi: $10.5220 / 0005555503930400$.

[36] R. M. Parizi, "On the gamification of human-centric traceability tasks in software testing and coding," 2016 IEEE/ACIS 14th Int. Conf. Softw. Eng. Res. Manag. Appl. SERA 2016, pp. 193-200, 2016, doi: 10.1109/SERA.2016.7516146.

[37] "HOT Token." https://hotoken.io/ (accessed Jul. 26, 2020).

[38] "Sandblock." https://sandblock.io/ (accessed Jul. 26, 2020).

[39] "The POINT Token System: Gamification And Achievements For The Blockchain | by Point Token | Medium.” https://medium.com/@point_token/the-point-token-systemgamification-and-achievements-for-the-blockchain-bc368978e365 (accessed Jul. 26, 2020).

[40] Y. Ueyama, M. Tamai, Y. Arakawa, and K. Yasumoto, "Gamification-based incentive mechanism for participatory sensing," 2014 IEEE Int. Conf. Pervasive Comput. Commun. Work. PERCOM Work. 2014, pp. 98-103, 2014, doi: 10.1109/PerComW.2014.6815172.

[41] I. Amsyar, E. Christopher, A. Dithi, A. N. Khan, and S. Maulana, "The Challenge of Cryptocurrency in the Era of the Digital Revolution: A Review of Systematic Literature," Aptisi Trans. Technopreneursh., vol. 2, no. 2, pp. 153-159, 2020.

[42] E. Choi, "Understanding User Motivations for Asking and Answering a Question on Brainly, Online Social Learning Network," 2016, doi: 10.9776/16512.

[43] D. Giannetto, J. T. Chao, and A. Fontana, "Gamification in a Social Learning Environment," Issues Informing Sci. Inf. Technol., vol. 10, pp. 195-207, 2013, doi: $10.28945 / 1806$.

[44] K. N. Laland and L. Rendell, "Social learning: Theory," Encyclopedia of Animal Behavior. pp. 380-386, 2019, doi: 10.1016/B978-0-12-813251-7.00057-2.

[45] J. E. Grusec, "Social learning theory and developmental psychology: The legacies of Robert Sears and Albert Bandura.," Developmental Psychology, vol. 28, no. 5. pp. 776786, 1992, doi: 10.1037//0012-1649.28.5.776.

[46] D. Tarasowa, A. Khalili, and S. Auer, "CrowdLearn: Crowd-sourcing the Creation of Highly-structured e-Learning Content," vol. 5, no. 4, pp. 47-54, 2015. 
[47] U. Rahardja, N. Lutfiani, E. P. Harahap, and L. Wijayanti, "iLearning: Metode Pembelajaran Inovatif di Era Education 4.0," Technomedia J., vol. 4, no. 2, pp. 261276, 2019, doi: 10.33050/tmj.v4i2.1010.

[48] H. Sun, X. Wang, and X. Wang, "Application of blockchain technology in online education," Int. J. Emerg. Technol. Learn., vol. 13, no. 10, pp. 252-259, 2018, doi: 10.3991/ijet.v13i10.9455.

[49] U. Rahardja, Q. Aini, and A. Khoirunisa, "Effect of iDu (iLearning Education) on Lecturer Performance in the Lecture Process," ATM, vol. 2, no. 2, 2018.

[50] "Quipper Indonesia | Distributors of Wisdom." https://www.quipper.com/id/ (accessed Jul. 26, 2020).

[51] "Bimbel Online No. 1 di Indonesia." http://bimbel.ruangguru.com/ (accessed Jul. 26, 2020).

[52] "Home - Zenius Education.” https://www.zenius.net/ (accessed Jul. 26, 2020).

[53] "Quipper, Zenius dan Solve Education! Serukan Pentingnya Memajukan Industri Edtech Bagi Pendidikan di Indonesia." https://dailysocial.id/wire/quipper-zenius-dansolve-education-serukan-pentingnya-memajukan-industri-edtech-bagi-pendidikan-diindonesia (accessed Jul. 26, 2020).

[54] A. B. Wandanaya and D. Rahmasary, "The Impact Analysis Of Stock Reminder Of Goods To Quality Company,” Aptisi Trans. Manag., vol. 3, no. 2, pp. 142-148, 2019.

[55] P. A. Sunarya, E. Budiarto, and F. H. N. Lestari, "Improved Management Understanding of Research Through Concepts and Preliminary Studies for Empirical Problem Solving," Aptisi Trans. Manag., vol. 2, no. 2, pp. 89-96, 2018.

[56] D. Johnson, A. Menezes, and S. Vanstone, "The Elliptic Curve Digital Signature Algorithm (ECDSA)," Int. J. Inf. Secur., vol. 1, no. 1, pp. 36-63, 2001, doi: $10.1007 / \mathrm{s} 102070100002$.

[57] M. Bafandehkar, S. M. Yasin, R. Mahmod, and Z. M. Hanapi, "Comparison of ECC and RSA algorithm in resource constrained devices," 2013 Int. Conf. IT Converg. Secur. ICITCS 2013, pp. 0-2, 2013, doi: 10.1109/ICITCS.2013.6717816.

[58] "Implementing the rivest shamir and," Adv. Cryptol. CRYPTO'86, pp. 311-323, 1986.

[59] J. T. Kim and W. H. Lee, "Dynamical model for gamification of learning (DMGL)," Multimed. Tools Appl., vol. 74, no. 19, pp. 8483-8493, 2015, doi: 10.1007/s11042-0131612-8.

[60] E. C. Daschmann, T. Goetz, and R. H. Stupnisky, "Testing the predictors of boredom at school: Development and validation of the precursors to boredom scales," Br. J. Educ. Psychol., vol. 81, no. 3, pp. 421-440, 2011, doi: 10.1348/000709910X526038.

[61] V. M. C. Tze, L. M. Daniels, and R. M. Klassen, "Evaluating the Relationship Between Boredom and Academic Outcomes: A Meta-Analysis," Educ. Psychol. Rev., vol. 28, no. 1, pp. 119-144, 2016, doi: 10.1007/s10648-015-9301-y.

[62] J. W. Brehm and E. A. Self, "The intensity of motivation.," Annu. Rev. Psychol., vol. 40, no. 1982, pp. 109-131, 1989, doi: 10.1146/annurev.ps.40.020189.000545.

[63] P. T. Wong, "Frustration, exploration, and learning.," Can. Psychol. Rev. Can., vol. 20, no. 3, pp. 133-144, 1979, doi: 10.1037/h0081509.

[64] "Unity Real-Time Development Platform | 3D, 2D VR \& AR Engine." https://unity.com/ (accessed Jul. 26, 2020).

[65] "Fusion 16 | Blackmagic Design." https://www.blackmagicdesign.com/products/fusion/ (accessed Jul. 26, 2020).

[66] "Android Platform | Android Developers." https://developer.android.com/about (accessed Jul. 26, 2020). 